\title{
Accessibility of public services in districts of Warsaw: a comparative study
}

\begin{abstract}
The aim of this work is to verify whether accessibility to public services in city districts of Warsaw, corresponds to real-estate prices. We introduce a new index named the "Urban Services Accessibility Index" (USAI) which compares the availability of public services within districts of a city in three dimensions: access to healthcare, access to education, and availability of public transport. We found that the districts of Śródmieście, Ochota and Żoliborz have the highest apartment prices and USAI values. Warsaw exhibits a clear distance-decay pattern in USAI values which correlates well with average apartment prices. This pattern results from poor development of public services in peripheral city districts (e.g. Bemowo, Białołęka, Wilanów) while the central district of Śródmieście stands out as the unquestionable leader in terms of accessibility to the mentioned services. USAI proved itself to be a robust method in the comparative analysis of city districts' development.
\end{abstract}

\section{Keywords}

Socio-economic inequalities $\cdot$ public services $\cdot$ Warsaw - city districts • distance-decay pattern

(C) University of Warsaw - Faculty of Geography and Regional Studies

\author{
Aleksander Małachowski $\mathbb{C}^{1}$, \\ Maciej Dąbski $\mathbb{C}^{2}$ \\ Waldemar Wilk $\mathbb{C}^{3}$ \\ ${ }^{1}$ Medical University of Warsaw, Warsaw, Poland \\ e-mail: alek.m1999@gmail.com \\ 2Department of Geomorphology, Chair of \\ Physical Geography, Faculty of Geography and \\ Regional Studies, University of Warsaw, Warsaw, \\ Poland \\ e-mail: mfdabski@uw.edu.pl \\ ${ }^{3}$ Chair of Urban Geography and Spatial Planning \\ Faculty of Geography and Regional Studies \\ University of Warsaw, Warsaw, Poland \\ e-mail: wwwilk@uw.edu.pl \\ Received: 1 October 2019 \\ Accepted: 21 May 2020
}

\section{Introduction}

In a geographical context, "access" is the quality of having interaction with, or passage to, a particular good, service, facility, or other phenomenon that exists in the spatiotemporal world (Talen 2001). In the public services context, "access" describes a state in which people can get to key services at reasonable cost, in reasonable time and with reasonable ease. The term includes a spatial aspect that focuses on evaluating the geographical distribution of specific objects - in our case, elements of public infrastructure.

In the scientific research we find many definitions of accessibility, including spatial, economic, and social perspectives. Often-used definitions include: opportunities for interactions Hansen (1959), the ease with which any activity can be reached from a given location via the public transport system (Dalvi \& Martin 1976), or the freedom of individuals to decide whether or not to participate in different activities (Burns 1979, cited in Geurs \& van Wee, 2004). Aoyama et al. (2011) state that the term "can be used for people to describe the ease with which they can reach places they want to go, such as hospitals, schools, shops, workplaces or national parks". The ways the term "accessibility" is used include referring to simple physical distance separating people and places, the ability (and willingness) to overcome those distances, and the ability to connect with information or people (usage of information technology). The concept of accessibility is still a central notion in socio-economic geographical studies.

Access to public services can be interpreted either as the measure of social capital development or an indicator (element) of quality of life, or even, according to Tsou et al. (2005) as spatial equity, which means equal access to basic public facilities, measured in distance and would even include choice of jobs. The concept also includes a social dimension, by considering whether societies are inclusive (enabling their members to participate in usual activities) and fair (by giving all members the opportunity to do so). This helps us to establish the relationship between the lack of accessibility to basic services and situations of exclusion in a geographical context.

Studies of accessibility to public services, regardless of spatial scale, are getting more common as the level of observed inequalities (economic and social) starts to rise. Polish geographers' growing interest in accessibility research is partly the consequence of the population's increased income and its tendency to stratify (Śleszyński 2014); therefore, more and more importance is being attached to quality of life and living conditions. However, existing studies are usually restricted to an isolated type of services, e.g. educational (Guzik 2003), or one specific area (Dominiak 2009). The first comprehensive study of differentiations in the level of public services accessibility in all municipalities in Poland was done by Stępniak et al. (2017). They looked at access to many categories of public services: public administration, childcare centres, different educational services, primary and specialist medical care, and cultural services (cinemas and theatres). There is also only a limited number of such studies focusing on Warsaw. Murawska (2013) elaborated a ranking of Warsaw city districts in relation to quality of life. The ranking serves as a major reference source for the discussion of our findings. A recent study by Kościńska (2019) must also be mentioned, but it is restricted to only three out of 18 city districts 
and based in part on surveys of inhabitants. In this context, our study attempts to fill the gap in this area.

This research uses a modified Human Development Index (HDI) as an indicator adopted to local differentiation (within city districts) of quality of life (United Nations Development Programme 2017a, b). Since its inception in 1990, HDI has become an important alternative to the traditional unidimensional measure of development (i.e. GDP). The aim of this work is to verify whether availability of public services in city districts of Warsaw, the capital of Poland, corresponds to the economic perception of the districts expressed by average real-estate prices. The public services under study include: healthcare, education, and public transportation. We selected these three services because they significantly influence the quality of life of an urban population. Being able to reach a medical centre quickly and having a short journey to school both count on reliable public transportation, and are frequently decisive criteria in choosing a place to live.

The concept of this study is based on the Human Development Index (HDI), a composite indicator used to measure the quality of life in countries (United Nations Development Programme 2017a, b). It combines several measures such as: life expectancy at birth, expected and mean years of schooling, and Gross National Income per capita at purchasing power parity (GNI per capita PPP) and transforms them into a single figure, ranging from 0 to 1. In 1997, an interesting attempt was made to adapt the HDI. S.J. Agostini and S.J. Richardson (1997) expanded the usage of the index to compare the quality of life between cities. In our study, we attempt to create a new index at the city district level called the "Urban Services Accessibility Index" (USAI), comparing the quality of life (measured by availability of healthcare, education, and public transportation) between the districts of Warsaw.

\section{Study site}

Warsaw is the capital and largest city of Poland, located in the Mazovian Voivodeship in the central-east of the country. The city is divided into 18 districts (Fig. 1) spread over a total area of $517 \mathrm{~km}^{2}$ and has a population of 1.7 million inhabitants (Główny Urząd Statystyczny 2017). The most populated city districts are Mokotów, Praga Południe, and Ursynów, and the least populated are Rembertów, Wesoła, and Wilanów (Table 1). About eighty percent of Warsaw was destroyed over the course of World War II, especially the west bank of the Vistula river (Majewski 2005). Today it is one of the most dynamic European cities, a cultural and economic hub, and a popular tourist destination.

Warsaw is characterised by a distance-decay pattern of apartment prices, with the most expensive being the centrally located Śródmieście and Ochota, and the cheapest being suburban districts, especially those of Białołęka and Ochota (Figs. 1, 2). Over thirty years have passed since the fall of the centrally planned economy in Poland, so the general pattern of prices can be explained by the classic bid-rent theory frequently used in urban studies (Shieh 2003). In this study only the prices of newly built apartments were considered (Domiporta 2017). The rationale behind this is that in terms of technical and architectural standards, newly built apartments are relatively homogeneous in all districts, which allows the role of location to be emphasised over a residential building's age.

\section{Methods}

Our concept is to compare the accessibility of public services in the districts of Warsaw by means of a universal indicator - the Urban Services Accessibility Index (USAI). The indicator is similar to HDI in the method of calculation, but the USAI compares the availability of public services within districts of a city in three dimensions: access to healthcare, access

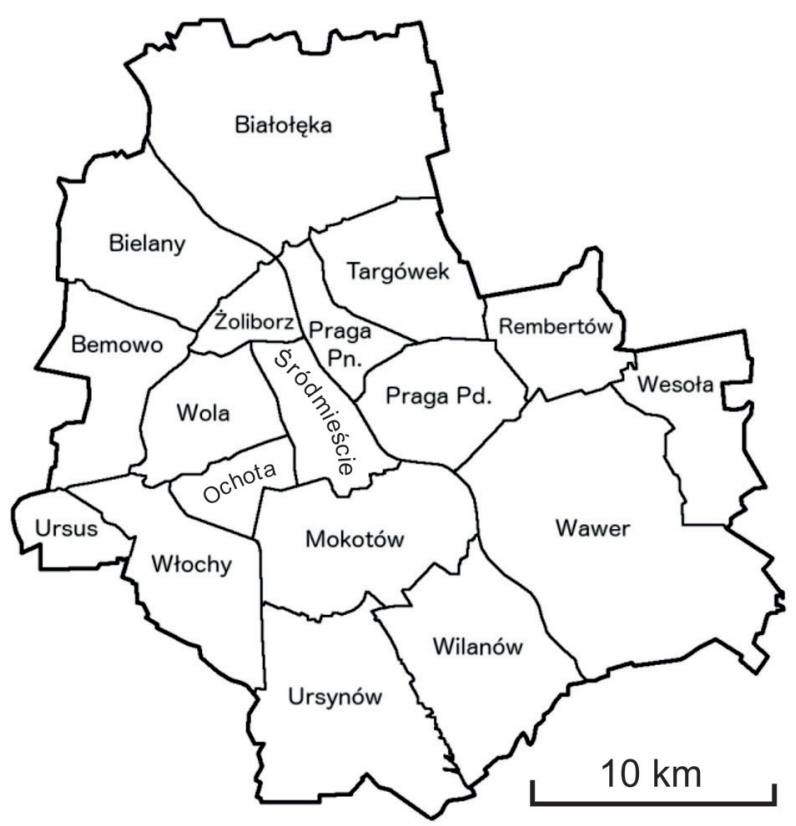

Figure 1. Map of Warsaw and its 18 districts.

Source: Metrohouse n.d. Available from: <https://metrohouse.pl/ news-jakie-dzielnice-warszawy-nas-interesuja->. [20 September 2019], modified

Table 1. Population of Warsaw city districts.

\begin{tabular}{|c|c|}
\hline City district & Population (in thousands) \\
\hline Mokotów & 217.8 \\
\hline Praga Południe & 178.4 \\
\hline Ursynów & 149.8 \\
\hline Wola & 138.5 \\
\hline Bielany & 132.0 \\
\hline Targówek & 123.5 \\
\hline Bemowo & 120.4 \\
\hline Śródmieście & 118.3 \\
\hline Białołęka & 116.1 \\
\hline Ochota & 83.6 \\
\hline Wawer & 74.9 \\
\hline Praga Północ & 65.9 \\
\hline Ursus & 58.2 \\
\hline Żoliborz & 50.8 \\
\hline Włochy & 41.4 \\
\hline Wilanów & 35.2 \\
\hline Wesoła & 24.8 \\
\hline Rembertów & 24.1 \\
\hline
\end{tabular}

Source: Główny Urząd Statystyczny 2017. Available from: <https://stat.gov.pl/obszary-tematyczne/ludnosc/ludnosc/powierzchnia-i-ludnosc-w-przekroju-terytorialnym-w-2017-r-,7,14. html>. [20 September 2019] 


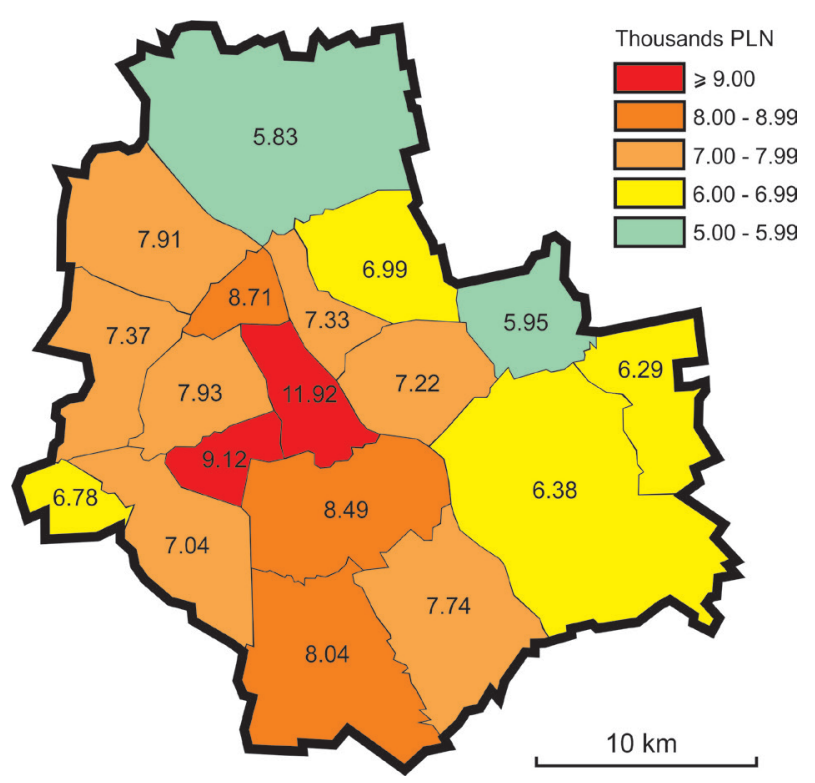

Figure 2. Average prices per square metre of new apartment in the districts of Warsaw. Source: Domiporta 2017. Available from: $<$ <ttp://www.domiporta.pl/poradnik/7,139461,21783457,srednieceny-mieszkan-w-warszawie-kwiecien.html>. [15 December 2018]

to education, and availability of public transport. For each dimension, the data is subject to a scoring system. For example, a primary school is awarded a higher number of points than a preschool, because it serves more people. Similarly, a regular bus line is awarded more points than a night line, and a multiward hospital gets many more points than a small health clinic. The USAI calculation takes into account the relative capacities of the districts, as it utilises the total scores (absolute capacities) divided by the number (in thousands) of people living in a given district. This was done in order to show how accessible public services are for the population of each city district.

\section{Scoring system for healthcare}

For this dimension, the Polish National Health Fund database was used to collect the data (Narodowy Fundusz Zdrowia n.d.). It was assumed that all the entries in this database have an agreement with the Fund and therefore are publicly accessible, and that the database is complete and contains every public healthcare centre in Warsaw. The database features three types of medical facilities: i) basic healthcare facilities, ii) specialised healthcare facilities, and iii) facilities with 24-hour care, i.e. hospitals. It contains a search engine with which it is possible to search for these facilities in each district of Warsaw separately. The entries in the database for the specialised facilities and hospitals were listed separately for each hospital ward or consulting office. Thus, a single hospital had many entries, as it possesses many wards. The scoring is based on counting the entries for each of the three categories, for all 18 districts. For an entry in the first category (basic care facilities), one point was awarded, whereas, for the second category (specialised facilities), two points were given. For 24-hour care facilities, three points were awarded for each entry.

\section{Scoring system for education}

The database of the Bureau of education of the Warsaw city hall was used while collecting the data for this dimension (Urzad m.st. Warszawy Biuro Edukacji 2017). It contained a list of preschools, primary schools and high schools in Warsaw. It was assumed that the database is complete and contains every public educational facility of the three types that are being investigated. Based on this database, preschool, primary, and high school entries were filtered for each district separately. Based on the level and comprehensiveness of education, and the abundance of schools of a given type, the schools were awarded points in this order: preschools - one point each, primary schools - two points each, high schools - three points each. The preschools, being the most abundant in Warsaw and offering the lowest level of education, were awarded the fewest points, whereas high schools, being the least abundant of the three types, as well as presenting the highest level of education, were awarded the largest number of points.

\section{Scoring system for public transportation}

For measuring the availability of transport, the official site of the Public Transport Authority was used (Zarząd Transportu Miejskiego w Warszawie n.d.). From the list of all bus and trams stops of a district, every stop name was put into a spreadsheet, specifying the number of public transport lines served by the stop: for every stop name, the number of tram lines was specified, as were bus lines for which the stop was a regular or "request" stop, and night lines. A "request" line is one for which a bus only stops at the stop when requested, for example by pressing a button in the bus, or a person wanting to ride the bus flagging the bus down by hand. For all the categories listed above, a scoring system was applied. The scoring guidelines were set by the estimated number of people a given type of public transport can transport within one hour. The most common tram in Warsaw, "PESA Swing" can take up to 200 people at once (Tramwaje Warszawskie 2015). Riding about six times an hour this gives a total number of 1,200 people per hour, assuming maximum turnover of passengers (all passengers disembark at each stop and all seats are again occupied by new passengers). The most capacious bus in Warsaw, the Solaris Urbino 18, can take up to 176 people at once, and riding about five times an hour gives a total of 880 people per hour (Solaris Urbino 18 2017). A night line in Warsaw rides approximately once an hour, yielding five times less than a regular bus. A suburban train can jet about 650 people in one go, and given that the trains depart every 15 minutes, this gives about 2,600 people an hour (Szybka Kolej Miejska Sp. z o. o. 2007). The subway rides every 2.5 minutes, giving a total of 24 rides an hour. A subway train can fit about 1,500 people, which gives a total of 36,000 people (Metro Warszawskie Sp. z.o.o. n.d.). Basing solely on these capacities, the scoring guidelines are as follows: A regular bus line being worth 1 point determines the value of a night line, which rides five times less, giving a sore of 0.2 points. A tram line can carry about $50 \%$ more people per hour. Therefore, a single line is worth 1.5 points. A suburban train carries about twice the number of people per hour that the tram does, so it is awarded 3 points. A subway, jetting 40 times more people an hour than a regular bus, is thus worth 40 points.

\section{Calculation of the USAI}

For each city district the points awarded in the scoring systems were divided by the population number of the district (population was divided by 1,000 for convenience). The population numbers in each district of Warsaw were taken from the report of Statistics Poland, and are present in the table below (Główny Urząd Statystyczny 2017).

The following calculation resembles that for the HDI (United Nations Development Programme 2017b). The minimum value for all three indices is zero, which translated to a situation with no health centre, school or public transportation in a given district, and was therefore omitted from the formula as having no impact on the 
outcome. The maximum value is the highest quotient (points awarded divided by population) for a particular dimension. The example formula below is for calculation of the dimension index for district $X$ in dimension $Y$ assuming that the highest quotient was calculated for district $Z$.

$D I_{Y}=\frac{\left(\frac{\text { points awarded for discrict } X \text { in dimention } Y}{\text { population of district } X}\right)}{\left(\frac{\text { points awarded for district } Z \text { in dimention } Y}{\text { population of district } Z}\right)}$

Once the dimension indices are calculated, the composite Urban Services Accessibility Index (USAI) is calculated by a geometric mean of the three dimension indices divided by district population:

$$
\begin{aligned}
& \text { USAI }=\sqrt[3]{\mathrm{DI}_{\mathrm{H}} \mathrm{DI}_{\mathrm{E}} \mathrm{DI}} \\
& \mathrm{DI}_{\mathrm{H}} \text { healthcare dimension index } \\
& \mathrm{DI}_{\mathrm{E}} \text { education dimension index } \\
& \mathrm{DI}_{\mathrm{T}} \text { transportation dimension index }
\end{aligned}
$$

To check the correlations between the USAI, apartment prices and the quality of life index by Murawska (2013) discussed later in the text, Pearson and Spearman correlation coefficients were calculated.

\section{Results}

The scores show that there are great differences between districts (Table 2). For example, in the sums for healthcare, Śródmieście district gathered 494 points, whereas Wesoła had only 30 , which is about 15 times less. This shows how different the districts are regarding absolute capacity and accessibility of public services. Significant differences are present in every dimension, but there are also many districts with comparable sums, like Targówek and Praga Północ in the healthcare dimension, or Ursynów and Wawer in the education dimension. The highest values for the healthcare, education and transportation dimensions are 536 (Mokotów), 212 (Mokotów) and 1,090.2 (Śródmieście), respectively. Using the values from tables 1 and 2, the dimension indices are calculated (Table 3).

Śródmieście has the highest values (1.000) of the education and transportation indices, but takes second place in the healthcare index ranking, ceding first place to Ochota. This is due to the significant number of hospitals in Ochota compared to its relatively small population. The worst accessibility to healthcare is in Bemowo (0.080), followed by Białołęka (0.090). In terms of accessibility to education, immediately after Śródmieście (1.000) comes Żoliborz (0.936) and then Wola (0.830). Education appears to be least accessible in Białołęka (0.256) and Bemowo (0.269). In terms of public transportation, Śródmieście (1.000) is far better than any other city district, because the second city district in this ranking is Praga Północ with a value of 0.563 . The worst accessibility of transportation is in Ursus (0.201) and Bemowo (0.219).

The highest USAI value was obtained, not surprisingly, for Śródmieście. It has by far the best accessibility of studied public services, with USAI of 0.916 , which is significantly greater than the second highest of 0.671 for Ochota. Mokotów, which was a leader in the scoring points ranking (Table 2) is only seventh in terms of USAI (0.483). This is because Mokotów has by far the largest population (Table 1). The districts of Białołęka and Bemowo obtained the lowest USAI index values, which is caused primarily by their poorly developed infrastructure and significant populations. City districts with the highest USAI values are situated near the centre of the city and the lowest values are found in peripheral districts (Fig. 3).
Table 2. Scoring points for each city district in the three dimensions

\begin{tabular}{|c|c|c|c|}
\hline City district & Healthcare & Education & Transportation \\
\hline Bemowo & 52 & 49 & 243.4 \\
\hline Białołęka & 57 & 45 & 320.5 \\
\hline Bielany & 206 & 107 & 445.4 \\
\hline Mokotów & 536 & 212 & 775.0 \\
\hline Ochota & 454 & 86 & 343.0 \\
\hline Praga Południe & 410 & 149 & 589.3 \\
\hline Praga Północ & 199 & 70 & 342.2 \\
\hline Rembertów & 44 & 20 & 89.8 \\
\hline Śródmieście & 494 & 179 & $1,090.2$ \\
\hline Targówek & 195 & 81 & 343.6 \\
\hline Ursus & 102 & 32 & 107.8 \\
\hline Ursynów & 240 & 62 & 413.5 \\
\hline Wawer & 289 & 58 & 262.4 \\
\hline Wesoła & 30 & 17 & 83.6 \\
\hline Wilanów & 46 & 19 & 80.6 \\
\hline Włochy & 40 & 34 & 186.9 \\
\hline Wola & 360 & 174 & 479.0 \\
\hline Żoliborz & 154 & 72 & 226.2 \\
\hline
\end{tabular}

Author: A. Małachowski

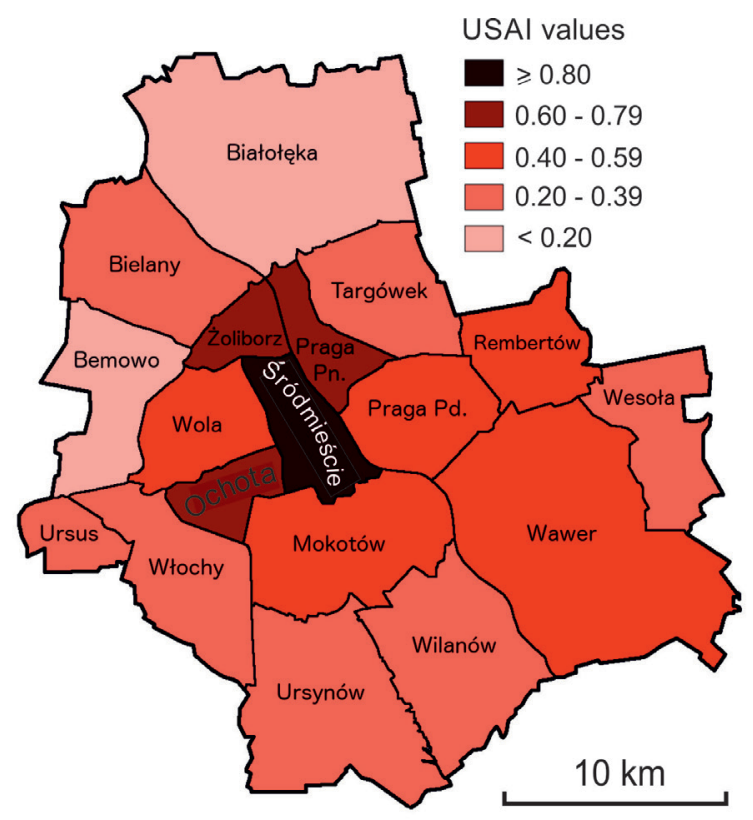

Figure 3. Pattern of USAI values in Warsaw Source: A. Małachowski 
MISCELLANEA GEOGRAPHICA - REGIONAL STUDIES ON DEVELOPMENT

Vol. $24 \cdot$ No. $3 \cdot 2020 \cdot$ pp. 176-182 •ISSN: 2084-6118 • DOI: 10.2478/mgrsd-2020-0019

Table 3. Dimension indices for healthcare, education transportation and USAI for districts of Warsaw

\begin{tabular}{|c|c|c|c|c|}
\hline City district & Healthcare index & Education index & Transportation index & USAI \\
\hline Bemowo & 0.080 & 0.269 & 0.219 & 0.167 \\
\hline Białołęka & 0.090 & 0.256 & 0.299 & 0.191 \\
\hline Bielany & 0.287 & 0.536 & 0.366 & 0.384 \\
\hline Mokotów & 0.453 & 0.643 & 0.386 & 0.483 \\
\hline Ochota & 1.000 & 0.680 & 0.445 & 0.671 \\
\hline Praga Południe & 0.423 & 0.552 & 0.358 & 0.437 \\
\hline Praga Północ & 0.556 & 0.702 & 0.563 & 0.604 \\
\hline Rembertów & 0.336 & 0.548 & 0.404 & 0.421 \\
\hline Śródmieście & 0.769 & 1.000 & 1.000 & 0.916 \\
\hline Targówek & 0.291 & 0.433 & 0.302 & 0.336 \\
\hline Ursus & 0.323 & 0.363 & 0.201 & 0.287 \\
\hline Ursynów & 0.295 & 0.273 & 0.299 & 0.289 \\
\hline Wawer & 0.710 & 0.512 & 0.380 & 0.517 \\
\hline Wesoła & 0.223 & 0.453 & 0.366 & 0.333 \\
\hline Wilanów & 0.241 & 0.357 & 0.249 & 0.278 \\
\hline Włochy & 0.178 & 0.542 & 0.490 & 0.361 \\
\hline Wola & 0.479 & 0.830 & 0.375 & 0.530 \\
\hline Żoliborz & 0.558 & 0.936 & 0.483 & 0.632 \\
\hline
\end{tabular}

Author: A. Małachowski

We found that the districts of Śródmieście, Ochota and Żoliborz have both the highest apartment prices (PLN 11,919, PLN 9,123, and PLN 8,707, respectively) and the highest USAI values $(0.916,0.671$, and 0.632 , respectively), and of the five districts with the lowest apartment prices (Białołęka, Rembertów, Wesołą, Wawer, and Ursus) two (Białołęka and Ursus) also have the USAI values in the bottom five. This shows that USAI and average apartment price show similar patterns of distance decay. The obtained Pearson correlation coefficient is equal to 0.742 , which shows a strong positive correlation between the two sets of data.

\section{Discussion}

Unequal access to public services can be considered a spatial, economic or social problem. Access defined on the basis of spatial distributions relates to the concept of spatial equity. It can be defined as equality, in which everyone receives the same access, regardless of socio-economic status, willingness to pay, or other criteria (Talen 2001). It is one of the reasons why geographers and other social science researchers are looking for a universal measure of accessibility and, in consequence, comprehensive quality of life indices (individual well-being). One of the obstacles we are confronted with is that public facilities exhibit a variety of characteristics. These characteristics include service range area, and spatial separation, of residents' preferences for different types of facilities, and the different sizes of public facilities of the same type, all of which have varying effects on the city residents. For example, a hospital located in one district attracts people from other parts of the city, which decreases its accessibility to the local population.

In order to manage some of these problems Geurs and van Wee (2004) identified - from the different definitions and practical measures of accessibility - four types of their components: landuse, transportation, temporal and individual. Especially important, in the context of our research, is the land-use component, because it:

reflects the land-use system within the city, consisting of (a) the amount, quality and spatial distribution opportunities supplied at each destination (jobs, shops, health, social and recreational facilities, etc.), and (b) the demand for these opportunities at origin locations (e.g. where inhabitants live), (c) the confrontation of supply of and demand for opportunities, which may result in competition for activities with restricted capacity such as job and school vacancies and hospital beds (Geurs \& van Wee 2004).

To some extent, the second component (transportation) is also included in our research. It describes the transport system, expressed as the supply of infrastructure, which includes its location and characteristics (e.g. maximum travel speed, number of lanes, public transport timetables, etc.).

Sagar and Najam (2008) discussed HDI calculation validity for local or regional levels of analysis and modifications of or improvements to the original index for measuring the links between the dimensions of human development and 
environmental sustainability. There are a few studies where HDI was used as an index of regional (local) social development. One of these studies (Tridico 2007) analyses the human development trend of Poland taking the HDI for the 16 Polish voivodships as the basic unit. Another one, done by Egri et al. (2009), used modified HDI as the measure of human development within regions (NUTS2) of Central and Eastern Europe countries. The authors proved the regional differences, not only in the studied entities but within certain countries also. It is beyond any doubt that composite indicators such as $\mathrm{HDI}$, with its modifications, help in comparative studies on spatial development.

In 2013 a report was published which focused on differences in quality of life (for the purpose of this article we name it the "QoL index") between different city districts of Warsaw (Murawska 2013). It took under consideration 11 elements such as: share of beneficiaries of social assistance benefits; green areas in total district area; or number of people per cinema, theatre and museum (combined). Similarly to our study, a clear distancedecay pattern was obtained with Śródmieście having the most attractive living conditions.

Our study results are also similar to the quality of life survey results ordered by Warsaw authorities. According to that survey, people living in peripheral districts expressed significantly lower levels of satisfaction with public transport accessibility (Rembertów, Wesoła) and quality of public educational institutions in their districts (Białołęka, Wesoła) (Badanie jakości życia 2019).

The aforementioned indices prove that there are numerous ways of analyzing patterns of quality of life in urban environments. Our USAI could be further developed by taking into account more elements of infrastructure, e.g.: accessibility to pharmacies (which are important in the healthcare system); adaptation of healthcare, education or transportation facilities to the needs of disabled persons; development of cycle paths and bicycle rental facilities; proximity to green areas. However, this would inevitably complicate calculation, and the results would probably show a pattern not very different from that obtained in this research.

\section{Conclusion}

Warsaw exhibits a clear distance-decay pattern in values of the Urban Services Accessibility Index (USAI), which correlates well with average apartment prices. This pattern results from the fact that the peripheral city districts (e.g. Bemowo, Białołęka, Wilanów) have poorly developed public-services infrastructure (education and transportation) in relation to their population size. On the other hand, the central district of Śródmieście stands out as the unquestionable leader in terms of accessibility to these services.

USAI - a modification of HDI - proved itself to be a robust method in the comparative analysis of city districts' development. In terms of using it to analyse quality of life differentiation on the local level, the HDI index needs further modifications to accommodate changes not only in living conditions but also in people's lifestyles.

\section{ORCID}

Aleksander Małachowski (D) https://orcid.org/0000-0002-4924-0000 Maciej Dąbski (1) https://orcid.org/0000-0003-1018-9639

Waldemar Wilk (1D) https://orcid.org/0000-0002-2462-6046

\section{References}

Agostini, SJ \& Richardson, SJ 1997, 'A Human Development Index for U.S. Cities: Methodological Issues and Preliminary Findings', Real Estate Economics, vol. 25, iss. 1, pp. 13-41.

Aoyama, Y, Murphy, JT \& Hanson, S 2011, Key Concepts in Economic Geography, Sage.

Badanie jakości życia mieszkańców warszawskich dzielnic 2015, 2015 [Survey of the quality of life of the residents of Warsaw districts carried out in 2015]. Available from: <http:// jakosczycia.um.warszawa.pl/>. [22 July 2019].

Domiporta 2017, Średnie ceny mieszkań w Warszawie Kwiecień [Average prices of apartments in Warsaw - Apri]. Available from: <http://www.domiporta.pl/poradnik/7,13946 1,21783457,srednie-ceny-mieszkan-w-warszawie-kwiecien. html>. [15 December 2018].

Dominiak, J 2009, Dostępność usług publicznych na terenie województwa wielkopolskiego [Availability of public services in the Greater Poland Voivodeship], Instytut Geografii Społeczno-Ekonomicznej i Gospodarki Przestrzennej UAM, Poznań. Available from: https://www.umww.pl/.../1. Dostępność $\% 20$ usług $\% 20$ publicznych $\% 20$ na $\% 20$ terenie\% $\%$. [20 June 2019].

Egri, Z, Töröcsik, V \& Tánczos, T 2009, 'Regional HDI as a territorial and social differentiation index in Central Europe' in New elements and research in spatial economy, ed. J Káposzta, Research Institute of J. Selye University, Komárno.

Geurs, KT \& van Wee, B 2004, 'Accessibility evaluation of land-use and transport strategies: review and research directions', Journal of Transport Geography, vol. 12, no. 2, pp. 127-140.

Główny Urząd Statystyczny 2017, Powierzchnia i ludność w przekroju terytorialnym w 2017 r. [Area and population in the territorial profile in 2017], Zakład Wydawnictw
Statystycznych, Warszawa. Available from: <https://stat. gov.pl/obszary-tematyczne/ludnosc/ludnosc/powierzchniai-ludnosc-w-przekroju-terytorialnym-w-2017-r-,7,14.html>. [20 September 2019].

Guzik, R 2003, Przestrzenna dostępność szkolnictwa ponadpodstawowego [Spatial availability of secondary education], Wydawnictwo Instytutu Geografii i Gospodarki Przestrzennej Uniwersytetu Jagiellońskiego, Kraków.

Harea, TS \& Barcus, HR 2007, 'Geographical accessibility and Kentucky's heart-related hospital services', Applied Geography, vol. 27, iss. 3-4, pp. 181-205.

Kościńska, J 2019, 'Miasto się rozlazło i teraz trzeba sobie z tym radzić. Analiza dostępności usług publicznych na podstawie wybranych dzielnic Warszawy' ['The city has spilled out and now you have to deal with it. Analysis of the availability of public services based on selected districts of Warsaw']. Conference materials: Warszawa $w$ świetle badań naukowych. Implikacje dla realizacji Strategii \#Warszawa2030 [Warsaw in the light of scientific research. Implications for the implementation of Strategy \#Warsaw2030]. Available from: http://2030.um.warszawa.pl/ warszawa-w-swietle-badan-naukowych/>. [20 June 2019].

Majewski, P 2005, Wojna i kultura. Instytucje kultury polskiej w okupacyjnych realiach Generalnego Gubernatorstwa 19391945 [War and culture. Polish culture institutions in the occupation reality of the General Government 1939-1945], Wydawnictwo TRIO, Warszawa.

Metrohouse n.d., Jakie dzielnice Warszawy nas interesują? [What districts of Warsaw are we interested in?], Available from: $<$ https://metrohouse.pl/news-jakie-dzielnice-warszawy-nasinteresuja->. [20 September 2019].

Metro Warszawskie Sp. z.o.o. n.d., Wagony serii INSPIRO. Metro Warszawskie [INSPIRO wagons. Warsaw Metro]. Available 
from: <http://www.metro.waw.pl/wagony-serii-inspiro>. [20 June 2017].

Murawska, E 2013, Ranking dzielnic Warszawy pod względem atrakcyjności warunków życia. Mazowiecki Ośrodek Badań Regionalnych [Ranking of Warsaw districts in terms of attractiveness of living conditions. Masovian Regional Research Center], Urząd Statystyczny w Warszawie. Available from: <https://warszawa.stat.gov. $\mathrm{pl} / \mathrm{files} / \mathrm{gfx} /$ warszawa/pl/defaultstronaopisowa/1094/1/1/ ranking_dzielnic_warszawy_pod_wzgledem_atrakcyjnosci_ warunkow_zycia_20131127.pdf>. [20 June 2017].

Narodowy Fundusz Zdrowia n.d., Zintegrowany Informator Pacjenta [Integrated Patient Guide]. Available from: <https:// zip.nfz.gov.pl/GSL/. [20 June 2018].

Sagar, AD \& Najam, A 2008, 'The human development index: a critical review', Ecological Economics, vol. 25, pp. 24-64.

Shieh, YN 2003, 'An early use of bid rent functions', Urban Studies, vol. 40, no. 4, pp. 791-795.

Solaris Urbino 18 n.d. Available from: <https://pl.wikipedia.org/ wiki/Solaris_Urbino_18>. [15 December 2018].

Stępniak, S, Wiśniewski, R, Goliszek, S \& Marcińczak, S 2017, 'Dostępność przestrzenna do usług publicznych w Polsce' ['Spatial access to public services in Poland'], Prace Geograficzne, vol. 261, IGiPZ PAN, Warsaw..

Szybka Kolej Miejska Sp. z o. o. 2007, Plan rozwoju spółki na lata 2007-2017 [Development plan for the years 2007-2017], Warsaw.

Śleszyński, P 2014, 'Dostępność czasowa i jej zastosowania' ['Temporal accessibility and its applications'], Przegląd Geograficzny, vol. 86, no. 2, pp. 171-215.

Talen, E 2001, 'Access: Geographical' in International Encyclopedia of the Social \& Behavioral Sciences, eds NJ Smelser \& BP Baltes, vol. 1, pp. 30-33, Elsevier Ltd, Oxford.

Tramwaje Warszawskie 2015, 120Na "Swing”. Available from: <https://tw.waw.pl/2015/10/29/120na-swing/>. [15 October 2017].

Tridico, P 2007, 'Institutions, human development and economic growth in transition economies', European Journal of Development Research, vol. 19, no. 4, pp. 569-593.

Tsou, KW, Hung, YT \& Chang, YL 2005, 'An accessibility-based integrated measure of relative spatial equity in urban public facilities', Cities, vol. 22, no. 6, pp. 424-435.

United Nations Development Programme 2017a, Human Development Index (HDI). Available from: <http://hdr.undp. org/en/content/human-development-index-hdi>. [20 July 2019].

United Nations Development Programme 2017b, Human Development Report. Available from: <http://hdr.undp.org/ sites/default/files/hdr2016_technical_notes_0.pdf>. [20 July 2019].

Urząd m.st. Warszawy Biuro Edukacji 2017, Edukacja Warszawska. Biuro Edukacji [Warsaw Education. Education Office]. Available from: <http://edukacja.warszawa.pl/ placowki/przedszkola>. [15 October 2017].

Zarząd Transportu Miejskiego w Warszawie n.d., Rozkłady jazdy z przystanku [Timetables from the stops]. Available from: $<\mathrm{http}: / /$ www.ztm.waw.pl/rozklad_nowy.php?c=183\&l=1>. [15 October 2017]. 